\title{
The Satisfaction Study of People with Disabilities Regarding the Restaurant with Barrier-Free Environment in Taiwan Tourism Area
}

\author{
Cheng Chia-Hsin ${ }^{1}$ \\ ${ }^{1}$ Hungkuo Delin University of Technology, Taiwan \\ Correspondence: Cheng Chia-Hsin, Hungkuo Delin University of Technology, Taiwan.
}

Received: January 16, 2020

Accepted: February 24, 2020

Online Published: March 6, 2020

doi:10.5539/ibr.v13n4p1

URL: https://doi.org/10.5539/ibr.v13n4p1

\begin{abstract}
The number of people with disabilities (PWDs) is expected to increase over years due to the increase of human lifespan and accidents. However, the PWDs as a result of some social factors, such as environment inaccessibility, insufficient job opportunity, inadequate education aids, etc. are excluded from participating their leisure activities or dining out in the society. This study aims to investigate and evaluate the design of barrier-free environment of restaurants in Taiwan famous tourism areas via the restaurant customer satisfaction of PWDs regarding the barrier-free facility and service quality. The results show that the qualified percentage of barrier-free physical environment design is only $44 \%$, and PWDs are not satisfied with the barrier-free physical environment including the space allotted in parking lots, restroom accessibility for PWDs, as well as the slipperiness of floors. The regression analysis shows the barrier-free physical environment and service quality aspect with respect to post-purchase intentions reach statistical significance indicating the environment design for the PWDs is critical to the restaurant management especially in a tourism area.
\end{abstract}

Keywords: PWDs, barrier-free environment, service quality, post-purchase intentions

\section{Introduction}

There are about 650 million people with disabilities (PWDs) in the world and about 5.7 million PWDs in Taiwan (Internal Labor Organization, 2018; Department of Social Welfare, 2018); According to the survey of Minister of the Interior, there are more than 2.9 million elderly people (over 65 years old) in Taiwan and $26 \%$ of the population are physical disabilities (Minister of the Interior, 2018). The number of PWDs is predicted to increase over years due to the ageing, accidents, diseases, etc. It is anticipated that 10 years from now, almost $20 \%$ of the world population will be over age 65 and the world will become a super-aged society. This percentage is particularly pronounced in Taiwan where the proportion of elderly people is growing at a faster rate. Thus, we can foresee a significant component of the changing disability profile, which is a direct consequence of the ageing of the population (WHO, 2007). Moreover, we must understand a fact that not only PWDs but also every person could face inconvenient situations at some stage of life requiring a wheelchair, having small children, being pregnant or elderly, or even becoming temporarily disabled sooner or later (Ferneeuw, 2005).

Previous research showed that PWDs have the right to acquire adaptive skills to engage in regular social interaction through dining out in restaurants or participating in recreational activities (Van Naarden Braun et al., 2006), which has been identified as a favorite factor in the necessity of communities for a better quality of life (Badia et al., 2011). Thus, dining out or participating in leisure activities has been an important fundamental right and also a goal of support services for PWDs (Luckasson et al., 2002). However, PWDs often experience limited opportunities to dine out or participate in leisure activities for various reasons (Yalon-Chamovitz and Weiss, 2008), such as environment inaccessibility (Kadir, Jamaludin and Rahim, 2012), ignorance in the policymaking system (Bickenbach et al., 1999) and public ignorance of PWDs rights and capabilities (Antonak and Livneh, 2000; Meyers et al., 2002; Putnam et al., 2003). The inaccessibility in various environments still limits PWDs to have chance for participating in the social, travelling, relaxation or rehabilitation, In order to ensure that equal opportunities for all people including PWDs should be created in Taiwan and PWDs can have the same rights and are treated equally in all areas of life, Taiwan government has started to promote a caring society incorporated with barrier-free environments, such as accessible living and tourism environment, assistant devices, barrier-free transportation facilities and buildings (Construction and Planning Agency Ministry of the Interior, 2018) accessible to everyone especially to the PWDs. Besides, the elderly people share many of the 
access barriers faced by disabled people, which infers that the disabled customers' market is an important niche market of the restaurants in famous tourism areas. Thus, the creation of barrier-free environments fully accessible and usable by disabled people can not only encourage PWDs to engage regular social interaction through dining out or traveling but also attract more tourists with diverse ages and backgrounds to the country (Jamaludin and Kadir, 2012) as well as generate tourism income.

According to previous studies, service quality is the key factor for business success and is pivotal to customer satisfaction in restaurant service marketing (Etzel, Walker and Stanton, 2001; Yuksel and Yuksel, 2003). Oliver (1980) stated that customer satisfaction can be an overall evaluation of performance based on prior experiences with a provider. Consequently, for service providers, it is important to satisfy customers so that they will affect their post-purchase intentions to become return customers ( Kivela et al., 1999, 2000; Chen et al., 2012 ).

Nevertheless, there has been relatively little academic research on the dine out in

the restaurants or travel of disabled people (Burnett and Bender, 2001; Darcy, 2002). If those PWDs are taken into account, the potential economic demand of addressing the restaurants or travel needs will be more benefit the tourism industry. In light of these concerns, this study aims to draw attention to the needs of PWDs in the design of the restaurants in famous tourism areas via customer satisfaction of the PWDs regarding a barrier-free environment and service quality. We hope the investigation can facilitate barrier-free environment design and good service quality in the restaurants as well as accessible tourism that focus on the needs of a broader range of users including PWDs to approach the subject from the perspectives of social justice and meet legal requirements rather than marketing purposes. Most people who have consensus on barrier-free environment have willingness to improve accessibility as well as build a save and convenient environment, regardless age, gender and physical differences, independently enjoy their ability to act.

\section{Literature Review}

\section{Conceptualizing People with Disabilities}

The UK Disability Discrimination Act (1995) describes people with disabilities (PWDs) as someone who "has a physical or mental impairment which has a substantial and long-term adverse effect on his/her ability to carry out normal day-to-day activities" (Var, et al., 2011). The study of Burnett and Bender (2001) clarified three terms with PWDs: impairment, disability and handicap. Impairment means any loss in health or abnormality of physiological, psychological, or anatomical function. Disability can be categorized into four different types: hearing disability, sight disability, physical disability and intelligence deficiency (Daniels, Rodgers and Wiggins, 2005) that results in restrictions on an individual's ability to perform an activity in their everyday society. Handicap is a condition in which part of individual's body or mind has been permanently damaged or does not work normally (depending on age, social or cultural factors). Lorant and Nicoletta (2011) defined disability or handicap as the permanent state or feature when a person's organ of sense or mobile, intellectual or communication skills considerably lags behind the average or even prevents a person from participating in social life. World Health Organization's ideology regards PWDs as "a complex phenomenon, reflecting an interaction between features of a person's body and features of the society in which he or she lives" (WHO, 2007). On the other hand, as the life span and numbers of elderly persons, many of whom have impairments. According to the survey of the World Bank shows that people spend on average about 8 years, or 11.5 percent of their life span was living with disabilities when their life expectancies over 70 years of age (World Bank, 2018).

In Taiwan, PWDs is defined as people who have physical, intellectual or sensory impairment, medical conditions or mental illness. Such impairments, conditions or illnesses may be permanent or transitory in nature (Lorant and Nicoletta, 2011) may affect to participate their activities and social life. Those people who need to get the PWDs document through the assessment of professionals such as doctors, social workers and special educations (Ministry of Health and Welfare, 2019). From the above, the imparity or disability can be congenital or may be caused by accident, illness or ageing. When individuals experience a serious illness, disabling condition or elderly, becoming the PWDs who not only will affect influence numerous areas of their life including self-care, mobility, communication, socialization and employment, but also have a significant difficulty to move around or significantly different tourism experience than others (Braithwaite, Waldron and Finn, 1999).

\section{Barrier-Free Environment In The Tourism Area}

The number of PWDs is continuously growing, according to the World Report on Disability launched by World Bank there are 1 billion people with a disability in the world, or 15\% of the population is disabled ( World Bank, 2018). In addition, due to the increasing aging populations in Taiwan, elder people more often suffer from 
functional limitations and mobility devices becomes more common (Parker et al., 2008). Therefore, accessibility is important for the PWDs, elderly, families with young children and the handicapped.

Accessibility for all is recognized as a basic necessity and all over the world attempts to ensure including to reach, to enter, to move around, to use (Masood and Shaheen, 2014) In other words, accessibility refers to a barrier-free environment. A barrier-free environment is a space designed to be free of obstacles. That allows free and safe movement, function and access for all, regardless of age, sex or conditions, a space or a set of services that can be accessed by all, without obstacles, with dignity and with as much independence as possible (Ferneeuw, 2005).

There are two scopes of the barrier-free environment, one is the physical environment, such as the design of the following: transportation facilities, buildings, roads, leisure and educational fields; the other is the invisible humane environment, such as acceptance, respect, service quality and the attitude aspects related (Wu et al., 1991). It must be clearly understood that the design concept of barrier-free environment not only a ramp but also many other necessary aspects, for instance entrances, corridors, elevators, stairs, doors, toilets, signage, operating mechanisms and fixed features(Masood and Shaheen, 2014). In a word, a barrier-free environment means one in which no obstacles will hinder PWDs or others from participating in activities in their life.

It is a good chance for PWDs to feel relax and recuperate via dining out or traveling on holiday (European Disability Forum, 2001). Which may considered a demand issue and create a new segment in tourism. Therefore, the goal of barrier-free environment in the tourism area is to provide services and equipment that help satisfy the needs of PWDs and elderly people so that they can enjoy their holiday and leisure activities without any disturbance.

\section{Service Quality}

Service quality has been defined as how well a customer's needs are met, and how well the service delivered meets the customer's expectations (Lewis and Booms, 1983). Gronroos (1984) indicated that the service quality is dependent on a comparison between customers' expected and perceived service, and is the outcome of a comparative evaluation process. Therefore, Etzel, Walker and Stanton (2001) thought service quality is measured by the customer and the service is expected compared to the actual measure of perceived service quality. Simply stated, expectations serve as a major determinant of a customer's service quality evaluations and satisfaction.

Understanding exactly what customers expect is the most crucial step in defining and delivering high-quality service (Zeitham et al., 1996). The literature is very rich in terms of definition, dimensions, models and measurement issues in service quality(Asubonteng et al., 1996; Dabholkar et al., 2000; Parasuraman et al., 1985). Among them, the SERVQUAL scale originally postulated in 1985 by Parasuraman, Zeithaml and Berry, is the most recognized approach to measuring service quality. This scale is measuring service quality in service industry, thus Stevens et al. (1995) modified several items from the original SERVQUAL and developed DINESERV to measure perceived service quality of restaurants customer (Richard et al., 1994). As follows:

- Reliability: Ability to perform the service dependably and accurately.

- Responsiveness: Willingness to help customers and provide customized service.

- Assurance: Knowledge and courtesy of employees make customers trust.

- Tangibles: Physical facilities, equipment and appearance of personnel.

- Empathy: Caring, individualized attention the firm provides for its customers.

\section{Post-Purchase Intention}

Post-purchase intention is the tendency that consumers will purchase the goods

or services at the same shop and deliver their use experiences to friends and relatives (Cronin et al., 2000; Zeithaml et al., 1996). Researchers use some variables to evaluate post-purchase intention, like as loyalty, pay more, repurchase intention and word of mouth (WOM) to assess the evaluation work (Zeithaml et al., 1996; Boulding et al., 1993). Which has been frequently used to inspect service quality (Boulding et al., 1993; Cronin and Taylor, 1992), and proves good service quality can induce positive purchase intention of customer. On the other hand, according to the study of Sivadass and Baker-Prewitt (2000) show that customer loyalty is the ultimate objective of customer satisfaction measurement. It is found to be a key determinant of a brand's long-term viability (Krishnamurthi and Raj, 1991). Thus, loyalty is defined as "a deeply held commitment to rebuy a preferred product/service consistently in the future (Kuo, Wub and Deng, 2009). In views of the preceding literature, we defined post-purchase as consumers are willing to buy a product or service on the same 
firm and continuously keep loyal patronage intentions, as well as willingness to recommend to friends and family and make further positive word of mouth.

Related Literature Research

According the literature review that we mention above, we list the related studies as shown in table 1:

Table 1. Related Literature Research

\begin{tabular}{|c|c|c|}
\hline Year & Author & Research Result \\
\hline 2011 & $\begin{array}{l}\text { Var, T., Yes, iltas M., Yaylı, A., O” } \\
\text { ztu“" rk,Y. }\end{array}$ & $\begin{array}{l}\text { To understand better the travel needs of people with a physical } \\
\text { disability }\end{array}$ \\
\hline 2006 & $\begin{array}{l}\text { Van Naarden Braun , K., } \\
\text { Yeargin-Allsopp, M., \& Lollar, D. }\end{array}$ & $\begin{array}{l}\text { To understand what kinds of factors associated with leisure activity } \\
\text { among young adults with disabilities. }\end{array}$ \\
\hline 2012 & Chung, C.C., \& Lue, C.C. & $\begin{array}{l}\text { To explore the demands of the dining service } \\
\text { for people who are visual impaired, }\end{array}$ \\
\hline 2019 & Liu, Y., Zou, M., \& Shi, L & $\begin{array}{l}\text { To understand what kinds of influencing factors for development of } \\
\text { barrier-free tourism for the disabled }\end{array}$ \\
\hline 1992 & Fornell & $\begin{array}{l}\text { To point out that high customer loyalty is mainly caused by high } \\
\text { customer satisfaction. }\end{array}$ \\
\hline 1994 & Richard et al., & $\begin{array}{l}\text { To develop DINESERV to measure perceived } \\
\text { service quality of restaurants customer. }\end{array}$ \\
\hline $\begin{array}{l}1996, \\
1993\end{array}$ & Zeithaml et al., \& Boulding et al., & $\begin{array}{l}\text { To use loyalty, pay more and repurchase intention as well as word of } \\
\text { mouth to evaluate post-purchase intention. }\end{array}$ \\
\hline 1991 & Westbrook \& Oliver & $\begin{array}{l}\text { To indicate satisfaction and repurchase intention as key determinants } \\
\text { of long-rang customer behaviors. }\end{array}$ \\
\hline
\end{tabular}

Owing to the restaurant belongs to service industry which is directly linked to the service provided to its customers. The industry must consider carefully all interested parties, even including the human rights of PWDs, which will result in not only good service performance, but also customer satisfaction. According to the purpose of this study and literature review, we propose the hypotheses for the study as below:

H1: A positive relationship exists between satisfaction of a barrier-free physical environment and post-purchase intentions for restaurants in the famous tourism area.

H2: A positive relationship exists between satisfaction of service quality and post-purchase intentions for restaurants in the famous tourism area.

H3: The satisfaction of having a barrier-free physical environment and good service quality of restaurants can positively predict post-purchase intentions.

\section{Method}

\section{Survey Instrument}

Based on a thorough literature review and the purpose, we chose the items to fit in our study according to the "Building Code Concerning Accessible" (Liao, 2006) as the first step to investigate and evaluate the barrier-free environment design of restaurant, including accessible parking space, ramps, slippery floor, main entrance, doorway, interior pathways, dining area, accessible restroom. In this part, we used the camera and tape measure to record the design. Then, we developed a self-administered questionnaire to understand the satisfaction of barrier-free physical environment and service quality of restaurant. All questionnaire used in this study consisted of three sections. In the first section of the questionnaire comprises 24 items to assess the satisfaction of the barrier-free physical environment and service quality of restaurants. The measurements and evaluation of the barrier-free physical environment as based on Building Code Concerning Accessible (Liao, 2006) and modified to fit in our study. The service quality scales are adopted from DINESERV techniques (Stevens et al., 1995) which is based on SERVQUAL by Parasurament et al. (1985), but is slightly modified to include the assessment of the invisible humane environment of restaurants. Because the DINESERV (Stevens et al., 1995) scale has been developed over decades and is used in numerous hospitality industry studies, the scale items can be used as the construct and appropriateness of the reference, and it not only has a certain reliability but also fits in with expert validity.

The second section asked about the customer satisfaction of the barrier-free physical environments and service quality of restaurants to reveal their post-purchase behavior and behavior intentions (González, Comesaña and Brea, 2007). Those items are measured using three questionnaires that were modified from Zeithaml et al. (1996) including giving recommendations to their friends (Boulding et al., 1993); willingness to return another time 
(Baker and Crompton, 2000) and willingness to make favorable word of mouth statements. All of these questionnaires use a 5-point Likert-type scale, ranging from 1 (strongly unsatisfied) to 5 (strongly satisfied). The final section reports on the respondents' relevant personal information including sex, age, occupation, education, and monthly income.

\section{The Pilot Study}

In order to ensure validity, reliability and clarity of the questionnaires, a total of 30 pilot questionnaires were undertaken at one restaurant similar to the population in the final study on September 24 to October 10, 2018. At this stage, participants were asked whether the items were appropriate for the questionnaires. The Cronbach's Alpha was .892 for the barrier-free physical environment and service quality section was .825 . All the values exceeded the minimum requirement of 0.7 and have been measured as adequate in meeting the criteria recommended by Nunnally (1978). These values indicate the internal consistency of the items.

\section{Data Collection Procedures}

Our study selected the "Sun Moon Lake Recreation Area" as the research area since it is the second famous national scenic resort area in Taiwan in 2018. Over 4,525,000 tourists visit this area every year (Tourism Bureau, 2018). At the same time, the county government is striving to make the Sun Moon Lake Recreation Area become the most important tourist site in Taiwan and is planning to make it an international, user-friendly, and barrier-free tour environment including enhancing the local restaurant service quality and sorting out main accessibility problems in surrounding environment of restaurant. Therefore, it is essential that restaurants of tourist attractions should be accessible to PWDs. A purposive sampling survey using self-administered questionnaires was adopted as the method of data collection for this study. Purposive sampling allows researcher intentionally choose participants who are relevant to the research questions. It was done at one family-style, full-service restaurant that has been certified "Gourmet TAIWAN" for eight years in the Sun Moon Lake Recreation Area since 2010 (Gourmet Taiwan, 2018). The questionnaires were collected from August 15 to October 25, 2016. Participants were recruited from various PWDs including wheelchair-bound, elderly people, ambulant disabled, and the temporary disabled (pregnant women are included) group as categorized by Harrison (2007). A total of 230 questionnaires were collected; however, 30 questionnaires were incomplete, which resulted in their deletion. The final sample size for statistical analysis was 200 . The response rate was $86.9 \%$.

\section{Results}

\section{Participants}

Table 2 summarizes the demographic profile of the respondents. Respondents consisted of $48.5 \%$ male participants and $51.5 \%$ female participants. Nearly $23.5 \%$ of the respondents were between the ages of 31 to 40 . Furthermore, $21.5 \%$ of the respondents were older than 61 years old, $41.5 \%$ of the participants have a college degree. Approximately $49 \%$ of the respondents spend between NT\$1,500 to NT\$4,500 a month to dine out.

Table 2. Demographic of Characteristics of Samples

\begin{tabular}{llr}
\hline Characteristics & Category & $\%(200)$ \\
\hline Gender & Female & $48.5 \%$ \\
Age & Male & $51.5 \%$ \\
& 20 or younger & $4.0 \%$ \\
& $21-30$ & $17.5 \%$ \\
& $31-40$ & $23.5 \%$ \\
& $41-50$ & $10.5 \%$ \\
Education & $51-60$ & $17.0 \%$ \\
& $61-70$ & $12.5 \%$ \\
Spending on food (NT) & 70 or older & $9.0 \%$ \\
Per mouth Outside & Junior High School & $15.5 \%$ \\
& Senior High School & $33.0 \%$ \\
& Bachelor & $41.5 \%$ \\
& less than 1,500 & $9.5 \%$ \\
& $1,501 \sim 3,000$ & $25.0 \%$ \\
& $3,001 \sim 4,500$ & $24.0 \%$ \\
& $4,501 \sim 6,000$ & $20.5 \%$ \\
\hline
\end{tabular}




\section{The results of barrier-free physical environment design}

Based on site observation and the standards of "Building Code Concerning Accessible ", the qualified percentage of barrier-free physical environment design is only $44 \%$ (See Table 3)

Table 3. The Results of Barrier-Free Physical Environment Design

\begin{tabular}{lcr}
\hline Items & Qualified Items/Examination Items & Qualified \\
\hline Accessible parking space & $0 / 2$ & $0 \%$ \\
Ramps & $1 / 1$ & $100 \%$ \\
Main entrance & $1 / 1$ & $100 \%$ \\
Doorway & $1 / 1$ & $100 \%$ \\
Slippery floor & $0 / 2$ & $0 \%$ \\
Interior pathways & $1 / 1$ & $100 \%$ \\
Dining area & $3 / 3$ & $100 \%$ \\
Accessible restroom & $1 / 7$ & $14.3 \%$ \\
Total Qualified $\%$ & $8 / 18$ & $44 \%$
\end{tabular}

\section{The results of factor analysis and reliability test}

SPSS 18.0 was used to test the reliability and construct validity of the scales according to factor analysis. Table 4 displays a summary of the factor analysis on the barrier-free physical environment and service quality. In the barrier-free physical environment and service quality parts, The Kaiser-Meyer-Olkin (KMO) overall measure of this part were 0.867 and 0.921 , respectively; which falls within the acceptable range. The Cronbach's $\alpha$ value of barrier-free physical environment and service quality factors are 0.886 and 0.915 , respectively. All the values fall within the acceptable range between 0.80 to 0.90 , which means very good (Kaiser and Rice, 1974).

Table 4. Results of Factor Analysis of Barrier-Free Physical Environment and Service Quality

\begin{tabular}{lccc}
\hline & KMO & Crobach's $\alpha$ \\
\hline Barrier-free Physical Environment & 0.867 & 0.886 & \\
Service Quality & 0.921 & 0.915 & \\
\hline
\end{tabular}

\section{Customer satisfaction of barrier-free physical environment}

The results of the descriptive statistics for the barrier-free physical environment are shown in Table 5, and the mean value (3.04) indicates that customers are satisfied with barrier-free physical environment design of the restaurant. Customers were especially satisfied for the width of the main entrance $(M=3.40)$, followed by the height of the tables $(M=3.38)$ and the height of the chairs $(M=3.38)$. However, customers were not satisfied with the space of parking lot allotted for disabled parking $(\mathrm{M}=2.53)$, accessibility of the restrooms $(\mathrm{M}=2.54)$ or slipperiness of the floor material $(\mathrm{M}=2.74)$.

Table 5. Results of Customer Satisfaction with Barrier-Free Physical Environment

\begin{tabular}{lccc}
\hline Items & $\mathrm{N}$ & Mean & Std.Deviation \\
\hline 1. The accessible ramp of slope & 200 & 2.94 & .949 \\
2. The width of the main entrance & 200 & 3.40 & .826 \\
3. Accessible Doorway & 200 & 3.24 & .985 \\
4.The width of the interior pathways & 200 & 3.09 & .831 \\
5.Slippery floor material & 200 & 2.74 & .987 \\
6.The width between tables of dining room & 200 & 3.04 & .822 \\
7.The height of tables of dining room & 200 & 3.38 & .713 \\
8.The height of chairs of dining room & 200 & 3.38 & .727 \\
9.Accessibility of the restroom & 200 & 2.54 & 1.074 \\
10.Accessible parking space & 200 & 2.53 & .102 \\
11.Satisfaction of barrier-free environment & 200 & 3.04 & \\
\hline
\end{tabular}




\section{Customer Satisfaction with service quality}

Table 6 shows the results of the descriptive statistics for the customer satisfaction of service quality. The mean value $(\mathrm{M}=3.40)$ indicates that customers were satisfied with service quality, especially with the appearance of the servers $(M=3.78)$, followed by having friendly and courteous attitudes $(M=3.68)$, and understanding people's needs $(M=3.55)$. The result were revealed that the service quality category with the lowest mean was for no barrier-free sign at the restaurant $(\mathrm{M}=2.70)$, and possibly restaurant has not completely executed the barrier-free environment design standard, and has ignored those PWDs who will also be their customers. Hence, the restaurant in the resort area needs to observe and better barrier-free label in design.

Table 6. Results of Customer Satisfaction with Service Quality

\begin{tabular}{llll}
\hline Items & N & Mean & Std. Deviation \\
\hline 12. Appearance of services & 200 & 3.78 & .630 \\
13. Servers can understand people's needs & 200 & 3.55 & .813 \\
14. Service is well timed & 200 & 3.53 & .701 \\
15. Servers can keep promise to customers & 200 & 3.48 & .750 \\
16. Neglectful service & 200 & 3.31 & .865 \\
17. Servers gave friendly and courteous attitude & 200 & 3.68 & .663 \\
18. Attention to cooperative and make the service well done & 200 & 3.51 & .773 \\
19. Customerized service & 200 & 3.20 & .819 \\
20. No difference in service for PWDs & 200 & 3.39 & .775 \\
21. Having barrier-free signs for facilitates & 200 & 2.70 & .047 \\
22. Operating time can satisfy customers & 200 & 3.23 & .746 \\
23. Service instills trust to customers & 200 & 3.46 & .715 \\
24. Satisfaction of service quality & 200 & 3.40 & .672 \\
\hline
\end{tabular}

\section{Descriptive statistics of post-purchase intentions}

After finishing assessing the barrier-free physical environment and service quality of restaurant, participants were asked about their post-purchase intentions. Table 7 summaries the results of post-purchase intentions, and the mean value indicates that customers have positive post-purchase intention behavior. The values are from 3.69 to 3.75 and indicate that most respondents are willing to recommend and make favorable world-of-mouth pronouncements about this restaurant to their friends or others, and also would like to return to this restaurant again.

Table 7. Results of Demographic of Post-Purchase Intentions

\begin{tabular}{lllc}
\hline Items & N & Mean & Std. Deviation \\
\hline Will to recommendations & 200 & 3.69 & .726 \\
Would like to Returning & 200 & 3.75 & .678 \\
Make favorable world-of-mouth & 200 & 3.75 & .819 \\
\hline
\end{tabular}

\section{The results of correlation analysis}

To explore the relationship between a barrier-free physical environment and service quality regarding post-purchase intentions, we employed Pearson correlation analysis. Table 8 shows a summary of the correlation statistics. The barrier-free physical environment and service quality aspect with respect to post-purchase intentions reached statistical significance $(r=.172, p<.05 ; r=.301, p<.001$, respectively). That means no matter the barrier-free physical environment or the service quality aspect with respect to post-purchase intentions have a positive relationship. Therefore, for PWDs, greater customer satisfaction results in higher post-purchase intentions. So, $\mathrm{H} 1$ and $\mathrm{H} 2$ were supported.

Table 8. Results of Correlationsfor Customer Satisfaction of Barrier-Free Physical Environment and Service Quality on Post-Purchase Intenions

\begin{tabular}{llcc}
\hline & $\mathrm{N}$ & Correlation & $p$-Value \\
\hline Barrier-free physical environment & 200 & .172 & $.015^{*}$ \\
Service Quality & 200 & .301 & $.000 * * *$ \\
\hline$* \mathrm{p}<05 * * * p<01 ; * * * p<001$ & & &
\end{tabular}




\section{The results of regression analysis}

To analyze the impact of satisfaction with a barrier-free physical environment, and service quality on post-purchase intentions, linear regression analysis was used. The results are shown in Table 9 . Table 9 displays the model summary of regression analysis with barrier-free physical environment and service quality as the independent variables and post-purchase intentions as the dependent variable. Regarding the barrier-free physical environment satisfaction aspect, it shows an $R_{\text {change }}^{2}$ of .039 , which means that a barrier-free physical environment's satisfaction can explain approximately $3.9 \%$ of the variance of post-purchase intention; and a barrier-free physical environment's satisfaction reached statistical significance $(F=8.002, p<.005)$; therefore, we can indicate that a barrier free physical environment's satisfaction of restaurant and post-purchase intentions are positively related. This means that when there is a higher satisfaction with a barrier-free physical environment, there is a greater post-purchase intention. Regarding the service quality aspect, it shows that the service quality satisfaction can explain approximately $11.6 \%\left(R_{\text {change }}^{2}=.116\right)$ of post-purchase intention, and yields meaningful results with statistical significance $(F=25.886, p<.000)$. This means that a higher satisfaction of service quality result shows greater post-purchase intention in restaurant. Thus, $\mathrm{H} 3$ was supported.

Table 9. The Model Summery of Regression Analysis Results

\begin{tabular}{lcccccc}
\hline $\begin{array}{l}\text { Independent } \\
\text { Variable }\end{array}$ & $F_{\text {change }}$ & $R_{\text {change }}^{2}$ & $\begin{array}{l}\text { Understandardized } \\
\text { Regression } \\
\text { Coefficient }(\beta)\end{array}$ & $\begin{array}{c}\text { Standardized } \\
\text { Regression } \\
\text { Coefficient }(\beta)\end{array}$ & $t$ & $p$-Value \\
\hline $\mathrm{B} / \mathrm{F} / \mathrm{P} / \mathrm{E}^{*}$ & 8.002 & .039 & .265 & .197 & 2.829 & $.005^{* *}$ \\
$\mathrm{~S} / \mathrm{Q} *$ & 25.886 & .116 & .350 & .340 & 5.088 & $.000^{* * *}$ \\
& & & & & & \\
$* \mathrm{p}<.05 ; * \mathrm{p}<.01 ; * * \mathrm{p}<.001$ & & & \\
$* \mathrm{~B} / \mathrm{F} / \mathrm{P} / \mathrm{E}=$ Barrier-free physical environment &
\end{tabular}

\section{Discussion}

From the site observation, we found the qualified percentage of accessibility environment is only $44 \%$, and disqualified items are listed as follows:

1. No obvious barrier-free symbols are labeled in the restaurant.

2. There is non-slippery floor material in dining areas and public/PWDs restrooms

3. The width of the door of accessible restroom is too narrow to enter for wheelchair users.

4. The space of restroom accessibility for PWDs is too small to turn round for wheelchair users.

5. There is no emergency button and handrail design in the restroom accessibility for PWDs.

6. Toilet seat is too low for PWDs.

7. No obvious barrier-free symbols are labeled and with obstacle in the parking lot.

According to the findings, we may suggest that restaurant can be further improved by providing better accessibility in the following aspects:

1. Using obvious barrier-free symbols and floor material that is slip-resistant in dining areas and public/PWDs restrooms.

2. Constructing real-accessible restrooms including larger turning space for wheelchair-users (the turn round space at least $150 \mathrm{~cm}$ ), and higher toilet seat up to $40 \mathrm{~cm}$. Moreover, the room must be equipped with an emergency button and handrail in the accessible restrooms.

3. Larger turning round space for wheelchair users is at least $150 \mathrm{~cm}$.

4. The width of the door of accessible restroom is need to bigger than $80 \mathrm{~cm}$.

5. Must be equipped with an emergency button and handrail on the toilet wall as well as raise the toilet seat higher to $40 \mathrm{~cm}$

6. Providing obvious barrier-free symbols and demolishing the obstacle in the parking space

As the satisfaction of the barrier-free physical environment and service quality, The results indicate that most customers were satisfied with the barrier-free physical environment including the width of the main entrance, the 
height of the tables and the height of the chairs, and those facilities design fit in with the standards for a barrier-free environmental design for restaurant (Liao, 2006); However, participants were not satisfied with the obvious accessibility space for PWDs allotted in the parking lots, the accessibility of the restrooms or the slipperiness of the floor materials. Since some PWDs need wheelchairs or crutches to help them move about, floor with a slip-resistant surface design would be preferable and less dangerous. Furthermore, obvious accessibility space allotted for PWDs' parking and restrooms with better accessibility would also be more convenient for PWDs, which would allow PWDs to use restroom facilities with requiring help. Thus, the barrier-free physical facilities of restaurants in the resort areas should improve the size of the restrooms and parking lots, or provided an adequate number of PWDs restrooms and parking lots with sufficient space and obvious barrier-free symbols as well as slip-resistant material for floors (Kadir, Jamaludin and Rahim, 2012).

Regarding to the service quality part, the findings indicate that customers were satisfied with the appearance of the servers, and that the servers could understand customer needs and had friendly and courteous attitudes. These results are consistent with the findings that service quality positively influences customer satisfaction as presented by Cronin et al. (2000) and Kristensen et al. (1999). When servers interact with PWDs directly, they are generally polite and make efforts to provide adequate service or care for them. And, they generally provide good service and have a positive attitude, even when they are busy. Hence, they can please customers and enhance their satisfaction level. Moreover, the study of Kose (2006) also indicated that helpful and friendly staff that is good at interacting with PWDs will be more effective with their business and service.

\section{Conclusion}

The study investigated the impact of customer satisfaction of barrier-free physical environments and service quality on post-purchase intentions with PWDs at restaurants in a famous resort area. Although, the statistical findings show that customer satisfaction and post-purchase intentions have a positive relationship; however, the values of customer satisfaction of restaurants on tangible and intangible dimensions only fall in "average" to "satisfied" range, which indicated that the barrier-free facilities design of restaurants still needs to improve to better serve PWDs' needs. Owing to people will experience changing abilities throughout their life span, we need to promote the concept of a "barrier-free environment" to the community and general public. To truly implement the standards for a barrier-free environment design to ensure the basic human rights of PWDs including being treated equally with non-PWDs, to enjoy the same restaurant environmental resources, and to be able to dine independently, restaurants need to provide a more inclusive environment that caters to the needs of a broader range of customers, especially PWDs. It is not easy to design a barrier-free environment and changing the environment design for existing restaurants, because that requires much capital expenditures and additional space. Under the limited budget, maybe the relative proprietors of restaurants can plan a space including dining environment, parking lot, restroom and walking pathway which conform to the standards of barrier-free environment. Finally, the duties of restaurant owner is need to train their staffs to be helpful and caring, with more empathy and patience, as well as giving them specific skills on how to communicate with PWDs. It is important that restaurants not only provide a barrier-free environment for all, but also provide equal convenience and courtesy to all their customers, because the implementation of inclusive design is significant in today's world (Imrie and Hall, 2011).

There are limits of this study: first, we investigate the barrier-free environment design of one restaurant in a tourism area but the results are not sufficient to represent all the restaurants around the tourism area. Second, we only adopt some standards to investigate the barrier-free environment design, whereas the results can not fully evaluate of the barrier-free environment design. Third, we only survey the participants who set in the wheelchairs. The results are, however, not enough to represent all the PWD's.

There are some implications: first, we hope all the people have the consensus on

the barrier-free environment and have willingness to improve accessibility. Second,

we hope the government can push forward the plan of barrier-free environment, ensure that everyone have the safe and convenient space environment as well as the same right to participate social activities and enjoy the service without discrimination.

For future studies, researchers may consider qualitative analysis to interview varieties of PWDs including visually-impaired or hearing-impaired persons regarding their perceptions on the accessible environment of other kinds of restaurants, tour destinations and public building environments, or to investigate the barrier-free job environment or accessibility job training in the hospitality industry from the perspective of staffs with disabilities. It can establish the measurement system for the public space to promote the friendly city, become the key factor to competitiveness of the country. 


\section{Reference}

Antonak, R. F., \& Livneh, H. (2000). Measurement of attitudes towards person with disabilities. Disability and Rehabilitation, 22(5), 211-244. https://doi.org/10.1080/096382800296782

Asubonteng, P., McCleary, K., \& Swan, J. (1996). SERVQUAL revisited: A critical review of service quality. Journal of Services Marketing, 10(6), 62-81. https://doi.org/10.1108/08876049610148602

Badia, M., Orgaz, B. M., Verdugo, M. A., Ullán, A. M., \& Martínez, M. M. (2011). Personal factors and perceived barriers to participation in leisure activities for young and adults with developmental disabilities. Research in Developmental Disabilities, 32, 2055-2063. https://doi.org/10.1016/j.ridd.2011.08.007

Baker, D. A., \& Crompton, J. L. (2000). Quality, satisfaction and behavior intentions. Annals of Tourism Research, 27(3), 758-804. https://doi.org/10.1016/S0160-7383(99)00108-5

Bickenbach, J. E., Chatterji, S., Badley, E. M., \& Ustun, T. B. (1999). Models of disablements, universalism and the international classification of impairments, disabilities and handicaps. Social Science \& Medicine, 48, 1173-1187. https://doi.org/10.1016/S0277-9536(98)00441-9

Boulding, W., Kalra, A., Staelin, R., \& Zeithaml, V. (1993). A dynamic process model of service quality: from expectations to behavioral intentions. Journal of Marketing Research, 30(1), 7-27. https://doi.org/10.2307/3172510

Braithwait, D. O., Waldron, R. V., \& Finn, J. (1999). Communication of social support in computer-mediated groups for people with disabilities. Health Communication, 11(2), 123-151. https://doi.org/10.1207/s15327027hc1102_2

Burnett, J., \& Bender, B. H. (2001). Assessing the travel related behaviors of the mobility-disabled consumer. Journal of Travel Research, 40, 4-11. https://doi.org/10.1177/004728750104000102

Chen, C. C., Cheng, C. H., Lin, S. Y., \& Tsai, C. C. (2012). Service quality and corporate social responsibility, influence on post-purchase intentions of shelter Employment institution. Research in Developmental Disabilities, 33, 1832-1840. https://doi.org/10.1016/j.ridd.2012.05.006

Chung, W. C., \& Lue, C. C. (2012). Barrier-free dining environment for the visually impaired: A case study of restaurant in Taichung, Taiwan. Current Issues in Hospitality and Tourism Research and Innovation. 2012 Taylor \& Francis Group, London.

Construction and Planning Agency Ministry of the Interior. (2018). The standards of designing accessible environment. Retrieved July 30, 2019, from http://free.abri.gov.tw/law_menu.php

Cronin, J. J., \& Taylor, S. A. (1992). Measuring service quality: a reexamination and Extension. Journal of Marketing, 56(3), 55-68. https://doi.org/10.2307/1252296

Cronin, J. J., Brady, M. K., \& Hult, G. T. M. (2000). Assessing the effects of quality, value, and customer satisfaction on consumer behavioral intentions in service environments. Journal of Retailing, 76(2), 193-218. https://doi.org/10.1016/S0022-4359(00)00028-2

Dabholkr, P., Shepherd, C. D., \& Thorpe, D. (2000). A comprehensive framework for service quality: an investigation of critical conceptual and measurement issues through a longitudinal study. Journal of Retailing, 76(2), 139-173. https://doi.org/10.1016/S0022-4359(00)00029-4

Daniels, M. J., Rodgers, E. B. D., \& Wiggins, B. P. (2005). Travel tales: An interpretive analysis of constraints and negotiations to pleasure travel as experienced by persons with physical disabilities. Tourism Management, 26(6). https://doi.org/10.1016/j.tourman.2004.06.010

Darcy, S. (2002). Marginalized participation: physical disability, high support needs and tourism. Journal of Hospitality and Tourism Management, 9, 61-73. Retrieved from https://www.researchgate.net/publication/235993175_Marginalised_participation_Physical_disability_high_ support_needs_and_tourism

Department of Social Welfare. (2018). Illness benefit. Retrieved July 20, 2019, from http://www.welfare.ie/en/Pages/345_illness-Benefit.aspx

Etzel, M. J., Walker, B. J., \& Stanton, W. J. (2001). Marketing Management (12th ed.). McGraw-Hill, Boston.

European Disability Forum. (2001). Position paper on tourism: framing the future of European tourism. Retrieved April 30, 2018, from http://ebookbrowse.com/edf-01-13-edf-response-on-framing-the-future-of the-european-tourism-doc-d12316761 
Ferneeuw, S. (2005). Guidelines for planning a barrier-free environment: a practical manual to improve physical accessibility in Afghanistan Step. Services Techniques et Etudes pour la Participation Sociale (STEPS): UNDP: Afghanistan.

Fornell, C. (1992). A national customer satisfaction barometer: the Swedish experience. Journal of Marketing, 56, 6-21. https://doi.org/10.1177/002224299205600103

González, M. E. A., Comesaña, L. R., \& Brea, J. A. F. (2007). Assessing tourist behavioral intentions through perceived service quality and customer satisfaction. Journal of Business Research, 60(2), 153-160. https://doi.org/10.1016/j.jbusres.2006.10.014

Gourmet Taiwan. (2018). The recommend restaurants for 2017 of Gourmet Taiwan. Retrieved July 27, 2019 from http://www.gourmettw-oqr.com/achievement.php

Grönroos, C. (1984). A Service quality model and its marketing Implications. European Journal of Marketing, 18(4), 36-44. https://doi.org/10.1108/EUM0000000004784

Harrison, J. (2007). Code on Accessibility in the Built Environment. B.C. Authority.

Imrie, R., \& Hall, P. (2001). Inclusive Design: Designing and Developing Accessible Environments. New York, NY.

Internal Labour Organization. (2018). Facts on disability and decent work. Retrieved April 16, 2019, from http://www.ilo.org/wcmsp5/groups/public/@ed_emp/@ifp_skills/documents/publication/wcms_117143.pdf

Jamaludin, M., \& Kadir, S. A. (2012). Accessibility in Buildings of Tourist Attraction: A case studies comparison. Procedia - Social and Behavioral Sciences, 35, 97-104. https://doi.org/10.1016/j.sbspro.2012.02.067

Kadir, S. A., Jamaludin, M., \& Rahim, A. A. (2012). Building managers perception in regards to accessibility and universal design implementation in public buildings: Putrajaya case studies. Procedia - Social and Behavioral Sciences, 35, 129-136. https://doi.org/10.1016/j.sbspro.2012.02.071

Kaiser, H. F., \& Rice, J. (1974). Little Jiffy, Mark IV. Educational and Psychological Measurement, 34, 111-117. https://doi.org/10.1177/001316447403400115

Kivela, J., Inbakaran, R., \& Reece, J. (1999). Consumer research in the restaurant environment. Part 1: A conceptual model of dining satisfaction and return patronage. International Journal of Contemporary Hospitality Management, 11(5), 205-222. https://doi.org/10.1108/09596119910272739

Kivela, J., Inbakaran, R., \& Reece, J. (2000). Consumer research in the restaurant environment. Part 3: Analysis, findings and conclusions. International Journal of Contemporary Hospitality Management, 12(1), 1-13. https://doi.org/10.1108/09596110010304984

Kose, S. (2006). Universal Design for the Aging. In International Encyclopedia of Ergonomics and Human Factors (2nd ed.). New York, NY. https://doi.org/10.1201/9780849375477.ch52

Krishnamurthi, L., \& Raj, S. P. (1991). An empirical analysis of the relationship between brand loyalty and consumer price elasticity. Marketing Science, 10(2), 172-183. https://doi.org/10.1287/mksc.10.2.172

Kristensen, K., Martensen, A., \& Gronholdt, L. (1999). Measuring the impact of buying behavior on customer satisfaction. Total Quality Management, 10(4/5). https://doi.org/10.1080/0954412997587

Kuo, Y. F., Wu, C. M., \& Deng, W. J. (2009). The relationships among service quality, perceived value, customer satisfaction, and post-purchase intention in mobile value-added services. Computers in Human Behavior, 25, 887-896. https://doi.org/10.1016/j.chb.2009.03

Lewis, R., \& Booms, B. (1983). The marketing aspects of service quality in Berry L, Shostack G and Upah G, Emerging Perspectives on Services Marketing. American Marketing Association Chicago, 99-107.

Liao, H. Y. (2006). A Research on Building Code concerning Accessible. Architecture and Building Research Institute. Taipei.

Liu, Y., Zou, M., \& Shi, L. (2019). Preliminary Study on the Development of Barrier-Free Tourism for the Disabled — Take Zhuhai Royal Hot Spring Resort as an Example. Advances in Economics, Business and Management Research, 91. 1st International Symposium on Economic Development and Management Innovation. Retrieved from file:///C:/Users/hsin3/Downloads/125914941\%20(1).pdf

Lorant, D., \& Nicoletta, K. (2011). Destination Development and Management for Disabled People. Journal of Tourism and Challenges and Trends, 4(2), 113-122. 
Luckasson, R., Borthwick-Duffy, S., Buntinx, W. H. E., Coulter, D. L., Craig, E. M., \& Reeve, A. et al. (2002). Mental retardation: Definition, classification, and systems of support (10th ed.). American Association on Mental Retardation. Washington, D. C.

Masood, H., \& Shaheen, S. S. (2014). Barrier free environment: An analysis of Aligarh City, India. International Journal of Interdisciplinary and Multidisciplinary Studies, 1(9), 8-15. Retrieved from http://www.ijims.com

Meyers, A. R., Anderson, J. J., Miller, D. R., Shipp, K., \& Hoenig, H. (2002). Barriers, facilitators, and access for wheelchair users: substantive and methodologic lessons from a pilot study of environmental effects. Social Science \& Medicine, 55, 1435-1446. https//doi.org/10.1016/S0277-9536(01)00269-6

Minister of Health and Wealfar. (2019). Identification for people with disability. Retrieved April 20, 2019, from http://www.mohw.gov.tw/cht/DONAHC/DM1_P.aspx?f_list_no $=588 \&$ fod_list_no $=1418 \&$ doc_no $=3440$

Minister of the Interior. (2018). The no. of people with disabilities in Taiwan. Retrieved July 20, 2019 from http://www.moi.gov.tw/stat/index.aspx

Nunnally, J. C. (1978). Psychometric Theory (2nd ed.). McGraw-Hill. New York, NY.

Oliver, R. L. (1980). A cognitive model of the antecedents and consequences of satisfaction decisions. Journal of Marketing Research, 17(4), 460-469. https://doi.org/10.2307/3150499

Parasuraman, A., Zeithaml, V., \& Berry, L. (1985). A conceptual model of service quality and its implications for future research. Journal of Marketing, 49, 41-50. https://doi.org/10.1177/002224298504900403

Parker, M. G., Sch"on, P., Lagergren, M., \& Thorslund, M. (2008). Functional ability in the elderly Swedish population from 1980 to 2005. European Journal of Ageing, 5, 299-309. https://doi.org/10.1007/s10433-008-0096-2

Putnam, M., Greenen, S., Powers, L., Saxton, M., Finney, S., \& Dautel, P. (2003). Health and Wellness: People with disabilities discuss barriers and facilitators to well-being. Journal of Rehabilitation, 69(1), 37-45. Retrieved from https://www.researchgate.net/publication/285633065_Health_and_wellness_People_with_disabilities_discu ss_barriers_and_facilitators_to_well_being

Richard, M. D., Sundara, D. S., \& Always, A. W. (1994). Service quality and choice behavior: an empirical investigation. Journal of Restaurant \& Foodservice, 93-109. https://doi.org/10.1300/J061v01n02_06

Sivadass, E., \& Baker-Prewitt, J. L. (2000). An examination of the relationship between service quality, customer satisfaction, and store loyalty. International Journal of Retail and Distribution Management, 28(2), 73-82. https://doi.org/10.1108/09590550010315223

Stevens, P., Knutson, B., \& Patton, M. (1995). DINESERV: A tool for measuring service quality in restaurants. Cornell Hotel and Restaurant Administration Quarterly, 36(2), 56-60. https://doi.org/10.1016/0010-8804(95)93844-K

Tourism Bureau. (2018). The no. of traveling people in the famous resort area of middle of Taiwan for 2018. Retrieved July 31, 2019, from http://admin.taiwan.net.tw/statistics/market_en.aspx?no=16

Van Naarden Braun, K., Yeargin-Allsopp, M., \& Lollar, D. (2006). Factors associated with leisure activity among young adults with developmental disabilities. Research in Developmental Disabilities, 27, 567-583. https://doi.org/10.1016/j.ridd.2005.05.008

Var, T., Yes ${ }_{s}$ iltas M., Yayl, A., \& O" ztu“ rk, Y. (2011). A study on the travel patterns of physically disabled people. Asia Pacific Journal of Tourism Research, 16(6), 599-618. https://doi.org/10.1080/10941665.2011.610143

Westbrook, R. A., \& Oliver, R. L. (1991). The dimensionality of consumption emotion patterns and consumer satisfaction. Journal of Consumer Research, 18(1), 84-91. https://doi.org/10.1086/209243

World Bank. (2018). The no. of disabilities in the world. Retrieved April 20, 2018, from https://www.disabled-world.com/disability/statistics/

World Health Organization. (2007). The definition of people with disabilities. Retrieved July 20, 2019, from http://www.who.int/ageing/age friendly cities/en/index.html

Wu, W. D., Chang, C. F., Lu, T. H., \& Tsai, C. J. (1991). The study of accessible campus environment from the view point of students with disabilities. Bulletin of Special Education, 7, 23-41.

Yalon-Chamovitz, S., \& Weiss, P. L. (2008). Virtual reality as a leisure activity for young adults with physical 
and intellectual disabilities. Research in Developmental Disabilities, 29, 273-287. https://doi.org/10.1016/j.ridd.2007.05.004

Yuksel, A., \& Yuksel, F. (2003). Measurement of tourist satisfaction with restaurant services: a segment-based approach. Journal of Vacation Marketing, 9(1), 52-68. https://doi.org/10.1177/135676670200900104

Zeithaml, V. A., Berry, L. L., \& Parasuraman, A. (1996). The behavioral consequences of service quality. Journal of Marketing, 60(2), 31-46. https://doi.org/10.2307/1251929

\section{Copyrights}

Copyright for this article is retained by the author(s), with first publication rights granted to the journal.

This is an open-access article distributed under the terms and conditions of the Creative Commons Attribution license (http://creativecommons.org/licenses/by/4.0/). 